APAE MEMO NO. 159

\title{
MATERIAL SPECIFICATIONS FOR APPR-1 CORE II \\ CONTROL ROD FUEL ELEMENTS
}

AND

ABSORBER SECTIONS

Contract No. AT (30-3) -278

Issued December 30, 1958

Authors - E.C. Edgar and R.D. Robertson

The specifications reported herein are based on the results of development performed at Oak Ridge National Laboratory under the supervision of the Metallurgy Division. This report partially fulfils the requirements of Amendment 2 to Contract $\operatorname{AT}(30 \cdot 3)-278$.

\section{Alco Products, Incorporated Post Office Box 414 Schenectady, N. Y.}




\section{DISCLAIMER}

This report was prepared as an account of work sponsored by an agency of the United States Government. Neither the United States Government nor any agency Thereof, nor any of their employees, makes any warranty, express or implied, or assumes any legal liability or responsibility for the accuracy, completeness, or usefulness of any information, apparatus, product, or process disclosed, or represents that its use would not infringe privately owned rights. Reference herein to any specific commercial product, process, or service by trade name, trademark, manufacturer, or otherwise does not necessarily constitute or imply its endorsement, recommendation, or favoring by the United States Government or any agency thereof. The views and opinions of authors expressed herein do not necessarily state or reflect those of the United States Government or any agency thereof. 


\section{DISCLAIMER}

Portions of this document may be illegible in electronic image products. Images are produced from the best available original document. 


\section{DISTRIBUTION}

Copies

1-3 New York Operations Office United States Atomic Energy Commission

70 Columbus Avenue

New York 23, New York

Att: Capt. R.L. Harris

4-6 United States Atomic Energy Commission

Army Reactors Branch

Division of Reactor Development

Washington 25, D.C.

Att: Major P.H. Ugis

7 A.L. Boch

8 J.E. Cunningham

ORNL

9 R.J. Beaver

ORNL

10

C.F. Leitten

ORNL

11 K. Kasschau

12

D.D. Foley

13 J.G. Gallagher

14 R.D. Robertson

15 R.W. Kelleman

16 R.A. Shaw

17

A.S. Wilder

18 E.C. Edgar

19-23

File 
MATERIAL SPECIFICATIONS FOR APPR 1 CORE II CONTROL ROD FUEL ELEMENTS AND ABSORBER SECTIONS

\subsection{INTRODUCTION}

The control rod fuel element consists of 16 flat composite fuel plates joined to a pair of side plates by brazing to form an integral assembly with a nominal water gap spacing of $0.133^{\prime \prime}$ $\$ 0.013^{\prime \prime}$ between fuel plates. Before brazing gussets are welded to the upper end of the side plates. After brazing a pin is inserted through holes in the end of the gussets and welded in place. The pin acts as a handle for loading and unloading the fuel element.

The core of the fuel plate contains an active fuel section and a flux suppressox section. The fuel section, composed of uranium dioxide, boron carbide and type 304LB stainless steel powder, is fabricated into a sintered compact by powder metallurgy techniques. The suppressor section, composed of europium oxide and elemental stainless steel powder, is also fabricated by powder metallurgy techniques.

The billet is prepared for hot rolling by inserting a fuel compact and a suppressor compact into a wrought stainless steel picture frame and enclosing with cover plates on the top and bottom surfaces of the frame. The cover plates are edge welded 
to the frame to form the billet. The billet is hot rolled to metallurgically bond the cover plates to the frame and the core in order to completely encase the fuel and suppressor sections. A thin jacket of stainless steel thus protects the core from the coolant, preventing the release of fission products from the fuel section.

The absorber section contains four absorber plates, joined by welding along the long edges to form a rectangular parallelepiped. A pin is attached to the upper end to facilitate handling during loading and unloading operations.

The core section of the absorber plate is a ceramet, fabricated by powder metallurgy techniques, composed of europium oxide dispersed in a matrix of elemental stainless steel. The billet for hot rolling is prepared by inserting cores wrapped with stainless steel diffusion barrier foil into a wrought stainless steel picture frame and enclosing with wrought stainless steel cover plates. The cover plates are edge welded to the picture frame to form a billet. The billet is hot rolled to promote bonding between the cover plates and the frame and core sections. The encasement jacket of stainless steel thus formed provides protection for the core against corrosion by the primary system coolant. 
2.0 CONTROL ROD FUEL ELEMENT SPECIFICATIONS

2.1 Number of Active Plates per Fuel Element

2.1 .1 Short plates

2.1 .2 Long plates

2

2.2 Core Material Requirements

2.2.1 Fuel

$$
\begin{array}{ll}
\text { U-235 per plate, gms } & 25.07 \\
\text { Enrichment, \% } & 93 \nsubseteq 1
\end{array}
$$

\section{Allowable Tolerances}

Weighing

Enrichment

$\mathrm{U}_{\mathrm{t}} / \mathrm{UO}_{2}$

Handling loss

2.2.2 Burnable Poison

B-10 per plate, gms

0.02264

\section{Allowable Tolerances}

Weighing

$\mathrm{B}_{\mathrm{n}} / \mathrm{B}_{4} \mathrm{C}$

Losses in sintering

Handling loss t0. $30 \%$

$\pm 1.00 \%$

$-7.00 \%$

$\$ 0.03 \%$

$\$ 0.10 \%$

$-0.20 \%$

$-0.20 \%$ t0. $25 \%$ 
2.2.3 Matrix Material

Type 304LB Stainless Steel Powder per Plate, gms.

91.51

Allowable Tolerances

Weighing

$\$ 0.01 \%$

Handling Loss

$-0.20 \%$

2.3 Suppressor Core Material Requirements

2.3.1 Suppressor Material

Europium per Plate, gms.

1.00

Allowable Tolerances

Weighing

$10.3 \%$

$\mathrm{Eu} / \mathrm{Eu}_{2} \mathrm{O}_{3}$

t0.5\%

Handling Loss

$-0.1 \%$

2.3.2 Suppressor Matrix Material

Elemental Stainless Steel Powder per Plate, gms.

Allowable Tolerances

Weighing $40.9 \%$

Handling Loss

$-0.3 \%$

In ORNL practice, individual suppressor cores were prepared from larger compacts. 


\subsection{Material Specifications}

2.4.1 Fue1

The fuel shall be uranium dioxide powder prepared by the "Geneva" process. This material is manufactured by the Y-12 Production Plant at Oak Ridge, Tennessee. The $\mathrm{W}_{2}$ shall contain approximately $88 \%$ total uranium and have a U-235 1sotopic concentration of $93 \% \neq 1 \%$. Particle size shall be 44-88 $\mu$. The $\mathrm{UO}_{2}$ powder shall be free of agglomerates, platelets, rods, and clinging surface fines.

\subsubsection{Burnable Poison}

The burnable poison material shall be natural boron carbide $\left(B_{4} C\right)$ powder equivalent to that supplied by Norton Chemical Company as High Purity Grade containing approximately $76 \%$ natural boron. Particle size shall be less than $44 \mu$.

\subsubsection{Fuel Core Matrix Material}

The matrix material shall be type 304LB stainless steel powder with a maximum carbon content of 0.03 wt.\% and a silicon content of approximately $2.5 \mathrm{wt} . \%$. The powder shall be equivalent to that supplied by Vanadium Alloys Steel Company, Latrobe, Pennsylvania. Particles shall be irregular in shape and less than $149 \mu$ in size. 


\subsubsection{Suppressor Material}

The suppressor material shall be high purity europium oxide $\left(\mathrm{Eu}_{2} \mathrm{O}_{3}\right)$, thoria free, containing a nominal 98 wt. \% europium oxide. The as-received material shall be high fired in a tungsten crucible under a dry hydrogen atmosphere for 3 hours at a temperature of $1700^{\circ} \mathrm{C}$. After firing the material shall be ground to a powder of less than $44 \mu$ size. After this treatment the material shall contain approximately 85 wt.\% europium.

\subsubsection{Suppressor Matrix Material}

The stainless steel matrix material shall be prepared from elemental electrolytic chromium, nickel and iron powders. The matrix content shall be approximately 18 wt. $\%$ chroo mium, 11 wt. \% nicke1 and 71 wt. \% iron. The maximum silicon and carbon contents of any of the elemental matrix powders shall each be less than 0.03 wt. $\%$.

\subsubsection{Wrought Stainless Steel}

A special grade of low cobalt AISI type 304L stainless steel shall be used as the clad and frame material in the fuel plates as well as for the side plates, combs, handles and pin of the fuel element. The carbon content shall be less than 0.03 wt. $\%$ and the cobalt content shall be less than 0.01 wt. $\%$. 


\subsubsection{Brazing Alloy}

The brazing alloy shall be Coast Metals, N.P. powder of less than $88 \mu$ size, obtained from Coast Metals, Inc., Little Ferry, New Jersey. This material shall be free of boron.

3.0 ABSORBER SECTION SPECIFICATION

3.1 Number of Plates per Absorber

4

3.2 Core Material Requirements

3.2.1 Absorber Material

Europium per Plate, gms.

151.00

Allowable Tolerances

Weighing

$\pm 0.3 \%$

$\mathrm{Eu} / \mathrm{Eu}_{2} \mathrm{O}_{3}$

$£ 0.5 \%$

Handling Losses

$-0.1 \%$

3.2.2 Matrix Material

Elemental Stainless Steel Powder per Plate, gms.

Allowable Tolerances

Weighing

$\$ 0.9 \%$

Handling Loss

$-0.3 \%$ 


\subsection{Material Specifications}

\subsubsection{Absorber Material}

The absorber material shall be high purity

europium oxide $\left(\mathrm{Eu}_{2} \mathrm{O}_{3}\right)$, thoria free, containing a nominal 98 wt. \% europium oxide. The as-received material shall be high fired in a tungsten crucible under a dry hydrogen atmosphere for 3 hours at a temperature of $1700^{\circ} \mathrm{C}$. After firing the material sha11 be ground to a powder of less than 44 $\mu$ size. After this treatment the material shall contain approximately 85 wt.\% europium.

\subsubsection{Matrix Material}

The stainless steel matrix material sha11 be prepared from elementai electrolytic chromium, nickel and iron powders. The matrix content shall be approximately $18 \mathrm{wt}$. $\%$ chromium, 11 wt. \% nickel and 71 wt. \% iron. The maximum silicon and carbon contents of any of the elemental matrix powders shall each be less than 0.03 wt. \% 。

\subsubsection{Diffusion Barrier Foil}

This foil stall be prepared by the powder rolling process from the elemental stainless steel powder specified in section 2.4 .5 . This foil shall be cold rolled to a thickness of about $0.004 "$ 。 


\subsubsection{Wrought Stainless Steel}

A special grade of low cobalt AISI type 304L stainless steel shall be used as the material for frame and clad material as well as for the handling pin. The carbon content shal1 be less than 0.03 wt. $\%$ and the cobalt content shall be less than 0.01 wt. $\%$.

\subsection{APPLICABLE DRAWINGS}

The following drawings, prepared by Alco Products, Inc., are applicable to the fabrication of the control rod fuel elements and absorber sections.

$$
\begin{aligned}
& \text { A9-13-2019 } \\
& \text { A9-13-2077 } \\
& \text { A9-13-2078 } \\
& \text { D9-13-1002 } \\
& \text { D9-13-1011 } \\
& \text { D9-13-2017 } \\
& \text { D9-13-2073 }
\end{aligned}
$$

